\title{
Wymiar fraktalny wybranych struktur złączy spawanych ze stali 15HM
}

\author{
The fractal dimension \\ of selected structures of $15 \mathrm{HM}$ steel joints
}

\section{Streszczenie}

Przedmiotem przedstawionych badań były struktury złącza spawanego ze stali 15HM. Głównym celem badań było określenie wymiaru fraktalnego wybranych struktur spoiny i strefy wpływu ciepła. W tym celu zastosowano cyfrowe przetwarzanie i analizę obrazu. Dla badanych struktur określono wymiar fraktalny pudełkowy i liniowy, wykorzystując odpowiednio metodę "Box Counting Dimension" (BCD) oraz jej modyfikację "Line Counting Dimension” (LCD).

Słowa kluczowe: wymiar fraktalny, struktura, strefa wpływu ciepła, spawanie

\begin{abstract}
The paper presents the results of fractal dimension measurements. The selected cross-sections structures of $15 \mathrm{HM}$ steel welded joint have been the subject of investigations.

The computer image processing techniques have been applied to prepare images of structures for measurements. Both box (BCD) and line (LCD) counting dimension algorithms have been used to obtain the fractal dimension of analyzed structures.
\end{abstract}

Keywords: fractal dimension, structure, heat affected zone, welding

\begin{abstract}
Wstęp
Struktura materiału konstrukcyjnego i jego skład chemiczny należą do najważniejszych czynników warunkujących uzyskanie określonych właściwości materiału. Stosunkowo prostą strukturą charakteryzują się materiały jednofazowe. Opis ich struktury na ogół nie nastręcza większych problemów. Inaczej przedstawia się sprawa w przypadku pozostałych materiałów. W większości z nich występuje znacząca różnorodność struktur. Mamy do dyspozycji materiały dwui wielofazowe, materiały charakteryzujące się występowaniem struktur pierwotnych i wtórnych, czy też np. materiały kompozytowe, gradientowe i nanomateriały. Analizowane struktury mogą ponadto składać się z jednego, dwóch lub wielu składników strukturalnych. W tych przypadkach opis nie zawsze jest prosty, wymaga stosowania odpowiednich narzędzi i metod, które pozwolą na określenie cech struktury i ich powiązań z właściwościami materiału. Do często stosowanych należą m.in. metody stereologiczne, a dzięki wzrostowi mocy obliczeniowej komputerów i dużej ich dostępności coraz częściej stosowane są metody komputerowe, wykorzystujące w szerokim zakresie przetwarzanie obrazów cyfrowych i ich analizę, rekonstrukcje trójwymiarowe czy symulacje komputerowe (np. oparte na metodzie Monte Carlo).
\end{abstract}

Jednym z interesujących narzędzi stosowanych do opisu otaczającej nas rzeczywistości, w tym także struktury materiałów konstrukcyjnych i procesów w nich zachodzących, jest geometria fraktalna. W literaturze krajowej i zagranicznej można znaleźć wiele publikacji związanych z jej zastosowaniem w badaniach materiałów $[1 \div 6]$. Metody oferowane przez geometrię fraktalną umożliwiają charakteryzowanie i modelowanie m.in. struktur o budowie dendrytycznej, przemiany martenzytycznej, granic ziaren i ich rozrostu, dwui trójwymiarowych struktur materiałów, struktury geometrycznej powierzchni, pękania materiałów.

Złącze spawane składa się ze spoiny, strefy wpływu ciepła i materiału rodzimego. Z tego powodu charakteryzuje się występowaniem zróżnicowanych struktur i zmiennymi właściwościami. Badanie przemian strukturalnych można prowadzić np. w warunkach symulowanych cykli cieplnych spawania [7]. Spoina w przypadku spawania jednowarstwowego posiada strukturę grubokrystaliczną, znamienną dla materiału lanego, a struktura materiału rodzimego jest charakterystyczna dla danego materiału i zależy od składu chemicznego stali i technologii jej wytwarzania. Najbardziej złożoną i zróżnicowaną część złącza spawanego stanowi strefa wpływu ciepła (SWC). Analizując budowę SWC moż-

Dr inż. Jarosław Grześ - Politechnika Warszawska.

Autor korespondencyjny/Corresponding author. jgrzes@wip.pw.edu.pl 
na wyróżnić następujące obszary: częściowego roztopienia, przegrzania, normalizacji, niepełnej krystalizacji i rekrystalizacji. Ze względu na występujące w niej zmiany strukturalne, zmiany związane $z$ rozrostem lub rozdrobnieniem ziaren oraz zmienność form geometrycznych składników strukturalnych i wzajemne przenikanie się poszczególnych jej obszarów, SWC wymyka się standardowym metodom opisu. Wykorzystanie możliwości cyfrowego przetwarzania obrazów, które coraz częściej jest stosowane w spawalnictwie $[8,9]$ i zastosowanie geometrii fraktalnej powinno umożliwić pełniejszą charakterystykę złączy spawanych.

\section{Pojęcie wymiaru fraktalnego}

Obiekty rzeczywiste niejednokrotnie mają skomplikowaną budowę, która uniemożliwia dokonanie pomiaru przy zastosowaniu tradycyjnych narzędzi. Klasycznym już przykładem obrazującym trudności z dokonaniem pomiaru jest określenie długości linii brzegowej. Okazuje się, że dokładny pomiar jest w tym przypadku niemożliwy. Przeprowadzając pomiar w warunkach naturalnych, w zależności od wielu czynników takich jak np. rodzaj użytego przyrządu do mierzenia i jego dokładność, stopień skomplikowania kształtu linii brzegowej, panujące w czasie pomiaru warunki (poziom i stan morza) itd., otrzymamy różne wyniki. Szybko okaże się, że pomiar w warunkach naturalnych traci sens i udzielenie odpowiedzi na pytanie, jaka jest długość linii brzegowej, jest praktycznie niemożliwe. Nie jesteśmy bowiem w stanie określić jej rzeczywistej długości. Jak zatem rozwiązać problem długości linii brzegowej i jak ją scharakteryzować? Z pomocą przychodzi geometria fraktalna, operująca m.in. pojęciem wymiaru fraktalnego. Zagadnienia związane z pojęciem wymiaru od lat są przedmiotem prac wielu matematyków. Efektem tych prac jest $\mathrm{m}$.in. istnienie różnych definicji wymiaru. Jako przykład niech posłużą wymiary: topologiczny, Hausdorffa, euklidesowy, korelacyjny, pojemnościowy, Lapunowa, fraktalny i wiele innych. Poszczególne wymiary są ze sobą powiązane. Do często stosowanych należą wymiary: samopodobieństwa, cyrklowy i pudełkowy; stanowiące szczególne przypadki wymiaru fraktalnego Mandelbrota, wywodzącego się z pracy F. Hausdorffa.

W wielu dziedzinach nauki dużą popularnością cieszy się wymiar pudełkowy. Zadecydowały o tym następujące jego zalety: mały stopień skomplikowania pomiaru, możliwość jego zautomatyzowania i szybkość pomiaru. Istotnym jest również to, że możemy stosować go zarówno w pomiarach obiektów (struktur) posiadających cechy samopodobieństwa (jedna z właściwości obiektu fraktalnego) jak i ich nie posiadających. Umożliwia pomiar obiektów płaskich i trójwymiarowych. Wskazuje, w jaki sposób obiekt wypełnia powierzchnię lub przestrzeń, w której się znajduje. Im wyższa wartość wymiaru fraktalnego, tym obiekt charakteryzuje się większą złożonością. Wymiar pudełkowy można zdefiniować następująco [10].

Def. Niech $\mathrm{N}_{\delta}(\mathrm{A})$ oznacza najmniejszą liczbę zbiorów o średnicy co najwyżej $\delta$, pokrywającą A - dowolny ograniczony podzbiór przestrzeni $R^{n}$. Wymiarem pudełkowym $D_{b}$ nazywamy granicę (o ile granica taka istnieje):

$$
D_{b}=\lim _{\delta \rightarrow \infty} \frac{\log N_{\delta}(A)}{\log 1 / \delta}
$$

gdzie: $D_{b}$ - wymiar pudełkowy, $N_{\delta}$ - najmniejsza liczba zbiorów pokrywających zbiór A, $\delta$ - średnica zbioru pokrywającego.

Odpowiedź na postawione wcześniej pytanie brzmi: należy przeprowadzić pomiar stopnia złożoności linii brzegowej poprzez określenie jej wymiaru fraktalnego, wykorzystując w tym celu prawo potęgowe wiążące długość linii brzegowej z dokładnością pomiaru.

\section{Metodyka pomiaru wymiaru fraktalnego}

Pomiar wymiaru fraktalnego badanych struktur oparto na wymiarze fraktalnym pudełkowym $D_{b}$ (Box Counting Dimension - BCD) i jego modyfikacji liniowej FDx i FDy (Line Counting Dimension - LCD).

W celu określenia wymiaru fraktalnego pudełkowego (BCD) badany obiekt pokrywa się regularną siatką o wielkości oczek s i zlicza się elementy siatki zawierające części obiektu (rys. 1). Standardowy algorytm postępowania wygląda następująco:

- na badaną strukturę nanosi się regularną siatkę kwadratową o wielkości oczka s,

- zlicza się oczka siatki, zawierające elementy struktury (N),

- w każdym kolejnym kroku zmniejsza się stopniowo s i znajduje odpowiadające im liczby oczek zawierających elementy struktury,

- punkty pomiarowe nanosi się na wykres zależności lo$\mathrm{gN}(\mathrm{s})=\log (1 / \mathrm{s})$

- do punktów pomiarowych dopasowuje się linię prostą (np. metodą najmniejszych kwadratów),

- oblicza się wartość współczynnika kierunkowego prostej. Wartość bezwzględna współczynnika kierunkowego prostej określa wymiar fraktalny $D_{b}$ badanej struktury. W literaturze można znaleźć opisy przedstawiające szczegóły realizacji efektywnych algorytmów określania wymiaru pudełkowego $[11 \div 14]$.
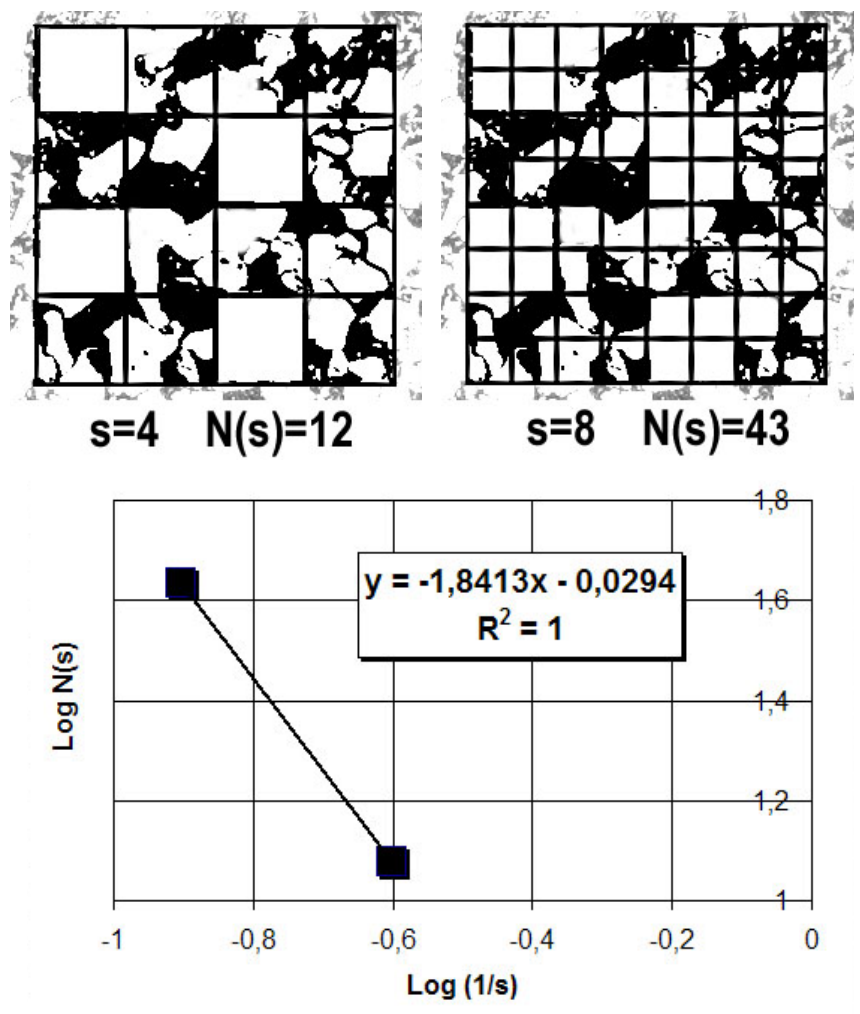

$$
\begin{aligned}
\log N(s) & =a \times \log \left(\frac{1}{s}\right)+b \\
D_{b} & =|a|
\end{aligned}
$$

Rys. 1. Zasada określania wymiaru fraktalnego - metoda BCD (opis w tekście)

Fig. 1. Calculation of the fractal dimension based on BCD method (see description in text) 
Metoda LCD (zmodyfikowana metoda BCD, w której kwadrat o boku s zastąpiono linią pomiarową) umożliwia określenie wymiaru fraktalnego liniowego FD i dokładne skanowanie analizowanej struktury. Zasadę pomiaru przedstawiono na rys. 2, a algorytm postępowania obejmuje:

a) nałożenie na badaną strukturę linii pomiarowej, podzielonej wstępnie na odcinki $L$,

b) dla danego położenia linii pomiarowej następuje jej dzielenie na coraz mniejsze odcinki L i zliczanie odcinków pokrywających elementy struktury $(\mathrm{N})$,

c) naniesienie punktów pomiarowych na wykres zależności $\log N(L)=\log (1 / L)$,

d) dopasowanie linii prostej do otrzymanych punktów,

e) określenie wymiaru fraktalnego równego wartości bezwzględnej współczynnika kierunkowego prostej,

f) przesunięcie linii pomiarowej o określoną liczbę pikseli (domyślnie przyjmuje się przesunięcie o 1 piksel, co umożliwia pełne skanowanie struktury),

g) powtórzenie kroków a)-f) aż do zeskanowania całej struktury.

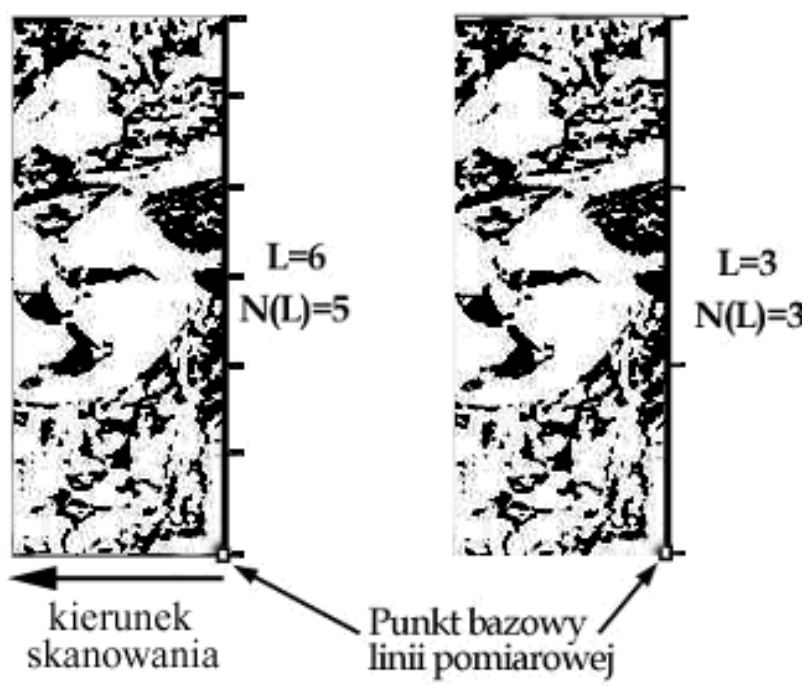

Rys. 2. Zasada określania wymiaru fraktalnego - metoda LCD (opis w tekście)

Fig. 2. Calculation of the fractal dimension based on LCD method (see description in text)

Wymiar fraktalny określono wykorzystując obrazy binarne struktur złącza spawanego oraz oprogramowanie opracowane w Zakładzie Inżynierii Spajania PW. W celu otrzymania obrazów binarnych zdjęcia struktur skanowano z rozdzielczością 300 dpi i przetworzono cyfrowo w progra- mie ImageJ. Wymiary obrazów poddanych analizie wynosiły $512 \times 512$ pikseli. Przyjęto procedurę postępowania podobną do opisanej w pozycji [15].

\section{Przedmiot badań}

Podstawowym celem przeprowadzonych pomiarów i określenia wymiaru fraktalnego było sprawdzenie przydatności zastosowania wymiaru fraktalnego (pudełkowego i liniowego) w analizie złącza spawanego. Przedmiotem analizy były struktury złączy ze stali 15HM (1.7335), należącej do grupy stali chromowo-molibdenowych i przeznaczonej do pracy w podwyższonych temperaturach (do 823K). Cechuje się ona dobrą plastycznością i jest stosowana m.in. na rury przewodowe, zbiorniki, części kotłów i turbin. W prezentowanych badaniach wykorzystano dokumentację fotograficzną będącą efektem wcześniejszych prac badawczych prowadzonych w Zakładzie Inżynierii Spajania PW.

Stal $15 \mathrm{HM}$ w stanie wyjściowym była normalizowana i odpuszczona. Złącza wykonano z rur o grubości ścianki $10 \mathrm{~mm}$ z ukosowaniem brzegów na V, spawanych łukowo ręcznie spoiwem ESCrMoR. Przed spawaniem zastosowano podgrzewanie wstępne do temperatury $573 \mathrm{~K}$. Złącza wykonano w dwóch wariantach: bez obróbki cieplnej (wariant I) i z zastosowaniem obróbki cieplnej ( $T=1023 \mathrm{~K}$ wariant II) po spawaniu. W celu ujawnienia struktury zgłady metalograficzne trawiono za pomocą $2 \%$ roztworu alkoholowego kwasu azotowego. Skład chemiczny stali 15HM (wg atestu hutniczego) i spoiwa ESCrMoR (na podstawie analizy chemicznej) podano w tablicy I, a parametry spawania w tablicy II.

\section{Wyniki badań Wymiar fraktalny struktur}

Wymiar fraktalny określono dla struktur złącza spawanego ze stali $15 \mathrm{HM}$, uwzględniając łącznie wszystkie ujawnione za pomocą trawienia elementy struktury takie jak granice ziaren, geometrię układu faz tworzących strukturę itp. $\mathrm{Na}$ rysunku 3 pokazano struktury złącza wykonanego $\mathrm{w}$ wariancie I (bez obróbki cieplnej po spawaniu). Stwierdzono występowanie struktur: sorbitycznej (spoina - warstwa graniowa i licowa, linia wtopienia, SWC - 1743K) oraz ferrytyczno-perlitycznej (SWC - 1073K, materiał rodzimy). Występowanie podobnych struktur stwierdzono dla złącza wykonanego w wariancie II (z obróbką cieplną po spawaniu), Poszczególne struktury dla tego złącza pokazano na rysun-

Tablica I. Skład chemiczny stali 15HM i spoiwa ESCrMoR, \% wag.

Table I. Chemical composition of 15HM steel and ESCrMoR electrode, wt\%

\begin{tabular}{|c|c|c|c|c|c|c|c|c|c|}
\hline Składnik & $\mathbf{C}$ & Mn & Si & P & S & Cr & Mo & Cu & Ni \\
\hline $15 \mathrm{HM}$ & 0,15 & 0,52 & 0,30 & 0,034 & 0,026 & 1,08 & 0,52 & 0,21 & 0,30 \\
\hline ESCrMoR & 0,065 & 0,54 & 0,18 & 0,030 & 0,026 & 0,90 & 0,58 & - & - \\
\hline
\end{tabular}

Tablica II. Parametry procesu spawania elektrodą otuloną

Table II. Experimental welding parameters for SMAW process

\begin{tabular}{|c|c|c|c|c|}
\hline Warstwa & $\begin{array}{c}\text { Średnica elektrody } \\
\text { [mm] }\end{array}$ & $\begin{array}{c}\text { Natężenie prądu } \\
\text { spawania [A] }\end{array}$ & $\begin{array}{c}\text { Napięcie tuku } \\
\text { [V] }\end{array}$ & $\begin{array}{c}\text { Szybkość spawania } \\
\text { [m/h] }\end{array}$ \\
\hline Spoiny sczepne & 2,5 & 110 & 26 & - \\
\hline 1 & 2,5 & 110 & 30 & 10 \\
\hline $2-3$ & 3,25 & 150 & 30 & 10 \\
\hline
\end{tabular}


ku 4. Twardość HV złącza zawierała się w granicach 290185 (wariant I) i 270-205 (wariant II).

W tablicy III zestawiono otrzymane dla analizowanych struktur wartości wymiaru fraktalnego pudełkowego $D_{b}$ i liniowego FDx i FDy oraz parametry statystyczne charakteryzujące ich rozkład. Wymiar liniowy określono dla kierunków skanowania: prostopadłego (FDx) i równoległego (FDy) do osi spoiny.

Na rysunkach 4 i 5 przedstawiono otrzymane wyniki $\left(D_{b}\right.$, FDx) w postaci graficznej. Pominięto wykresy dla wymiaru FDy ze względu na podobny charakter zmian jak w przypadku FDx. W celu zobrazowania charakteru zmian wymiaru fraktalnego liniowego, na rysunku 6 pokazano wykresy zmian oraz histogramy rozkładu jego wartości dla dwóch przykładowych struktur, pochodzących z obszaru linii wtopienia i przedstawionych na rysunkach $3 \mathrm{c}$ i 4c. Dla większości badanych struktur zaobserwowano histogramy przedstawiające rozkład o charakterze jednomodalnym.

Analiza wartości wymiaru fraktalnego $D_{b}$ oraz FDx i FDy dla poszczególnych struktur złącza ze stali $15 \mathrm{HM}$ wykazała na ogół podobne tendencje zmian jego wartości. Dla wariantu I wykonania złącza najwyższą wartością pudeł-
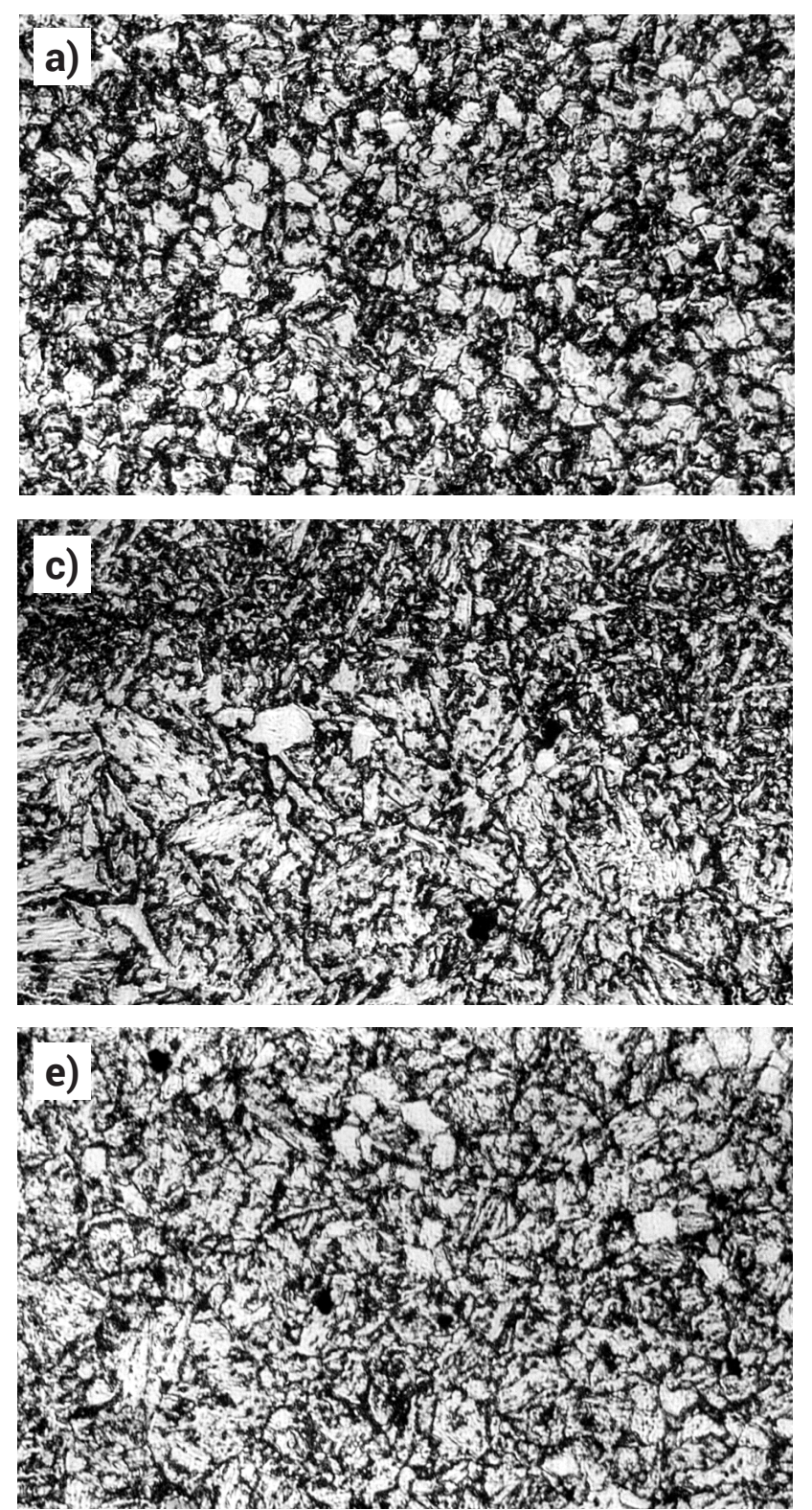

kowego wymiaru fraktalnego charakteryzuje się struktura materiału rodzimego $\left(D_{b}=1,8019\right)$, a najniższą struktura warstwy licowej $\left(D_{b}=1,7246\right)$. Średnie wartości liniowego wymiaru fraktalnego dla tych struktur wynoszą odpowiednio: $F D x=0,8319$ i $F D y=0,8265$ oraz FDx=0,7792 i $F D y=0,7765$. Z kolei dla wariantu II wykonania złącza najwyższą wartość pudełkowego wymiaru fraktalnego stwierdzono dla struktury obszaru SWC, nagrzanego do ok. 1073K $\left(D_{b}=1,7809\right)$. Dla tego obszaru stwierdzono również najwyższe średnie wartości FDx i FDy $(0,8218$ i 0,8200). W przypadku wariantu II zaobserwowano znaczący spadek wartości wymiaru dla obszaru linii wtopienia $\left(D_{b}=1,6821\right)$ i obszaru SWC nagrzanego do ok. 1473K $\left(D_{b}=1,6557\right)$. Takiego efektu nie zaobserwowano dla wariantu I. Dla rozkładów wartości wymiaru FDx i FDy poszczególnych struktur stwierdzono w większości przypadków stosunkowo niewielkie różnice w wartościach rozstępu, nie przekraczające 0,08 (wariant I) i 0,05 (wariant II z wyłączeniem obszaru linii wtopienia, dla którego różnica przekracza nieznacznie 0,15). Obliczony współczynnik zmienności, będący jedną z miar zróżnicowania rozkładu danej cechy, zawiera się w granicach 3,77 $-9,77 \%$ dla wariantu I i 4,19-10,01 dla wariantu II.
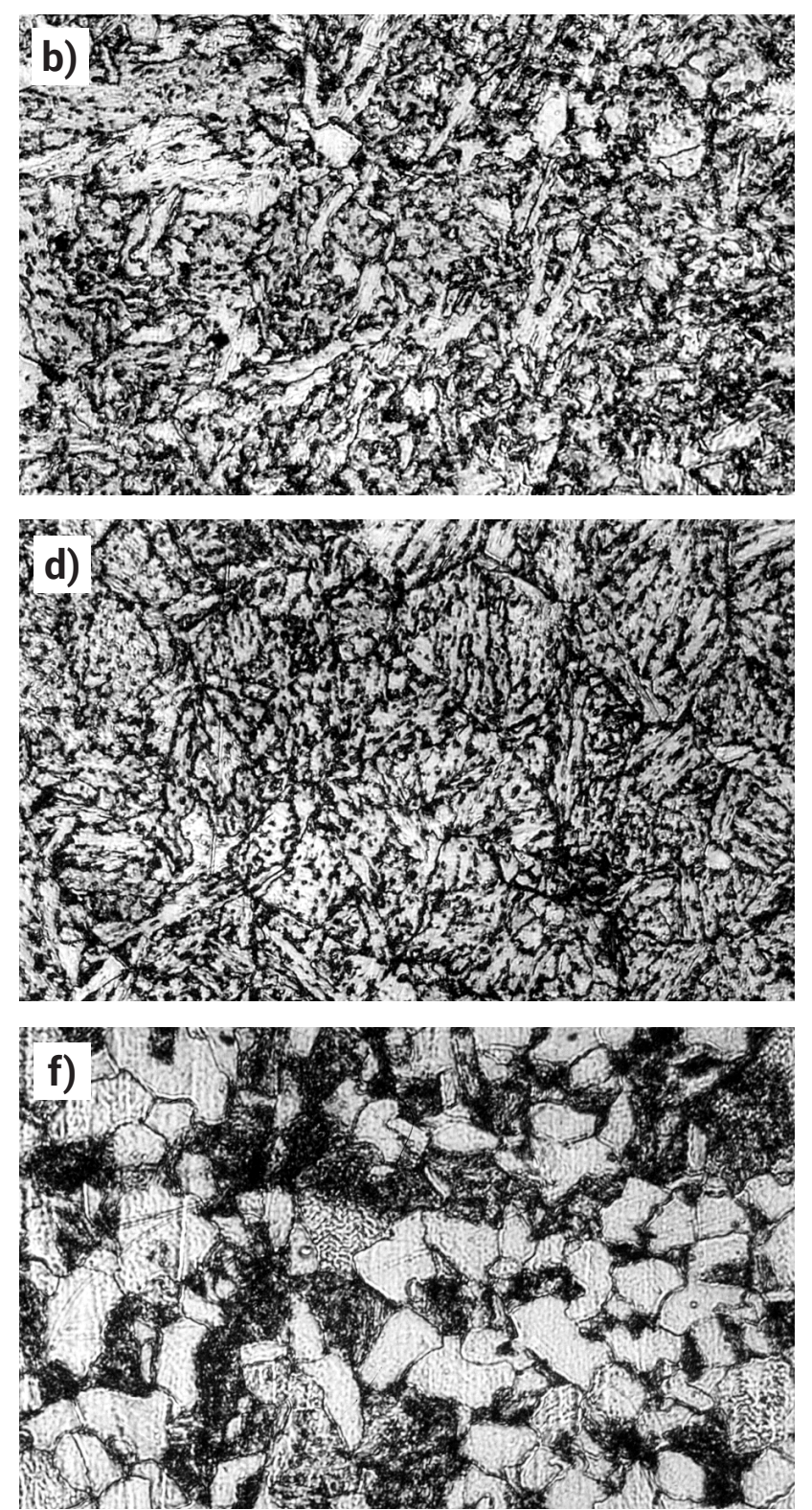

Rys. 3. Struktura spoiny, SWC i materiału rodzimego - wariant I (pow. 200x): a) spoina - warstwa graniowa, b) spoina - warstwa licowa, c) linia wtopienia (na górze widoczna spoina, na dole obszar przegrzania SWC), d) SWC - obszar nagrzany do ok. 1473K, e) SWC - obszar nagrzany do ok. 1073K, f) materiał rodzimy

Fig. 3. Structure of weld, HAZ and base material - variant I (x 200): a) root weld pass, b) face weld pass, c) fusion line - weld at the top, grain growth zone at the bottom, d) HAZ - zone heated up to about 1473K, e) HAZ - zone heated up to about 1073K, f) base metal 

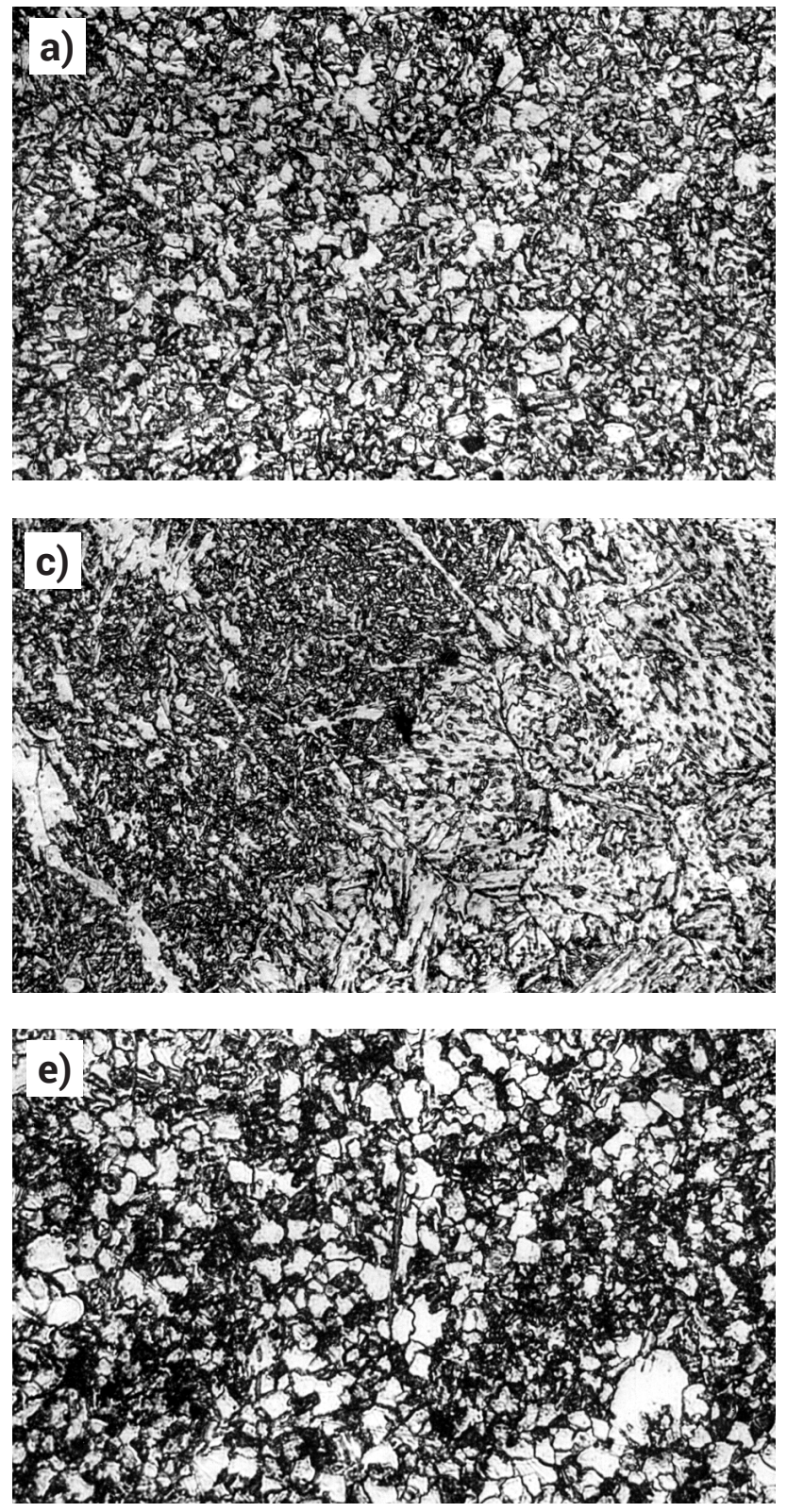
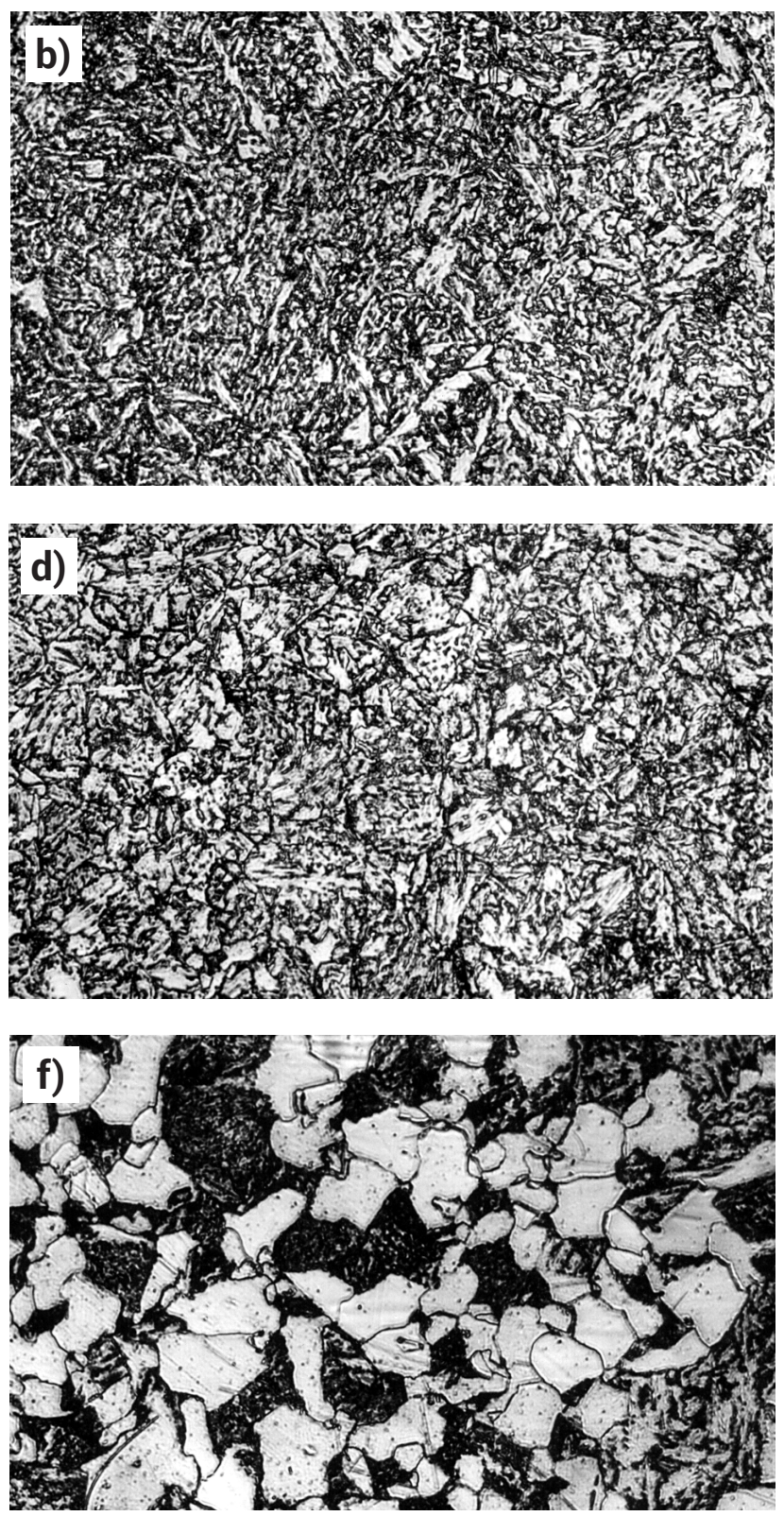

Rys. 4. Struktura spoiny, SWC i materiału rodzimego - wariant II (pow. 200x): a) spoina - warstwa graniowa, b) spoina - warstwa licowa, c) linia wtopienia (z lewej strony widoczna spoina, z prawej obszar przegrzania SWC), d) SWC - obszar nagrzany do ok. 1473K, e) SWC obszar nagrzany do ok. 1073K, f) materiał rodzimy

Fig. 4. Structure of weld, HAZ and base material - variant II (x 200): a) root weld pass, b) face weld pass, c) fusion line -weld from left side, grain growth zone from right side, d) HAZ - zone heated up to about 1473K, e) HAZ - zone heated up to about 1073K, f) base metal
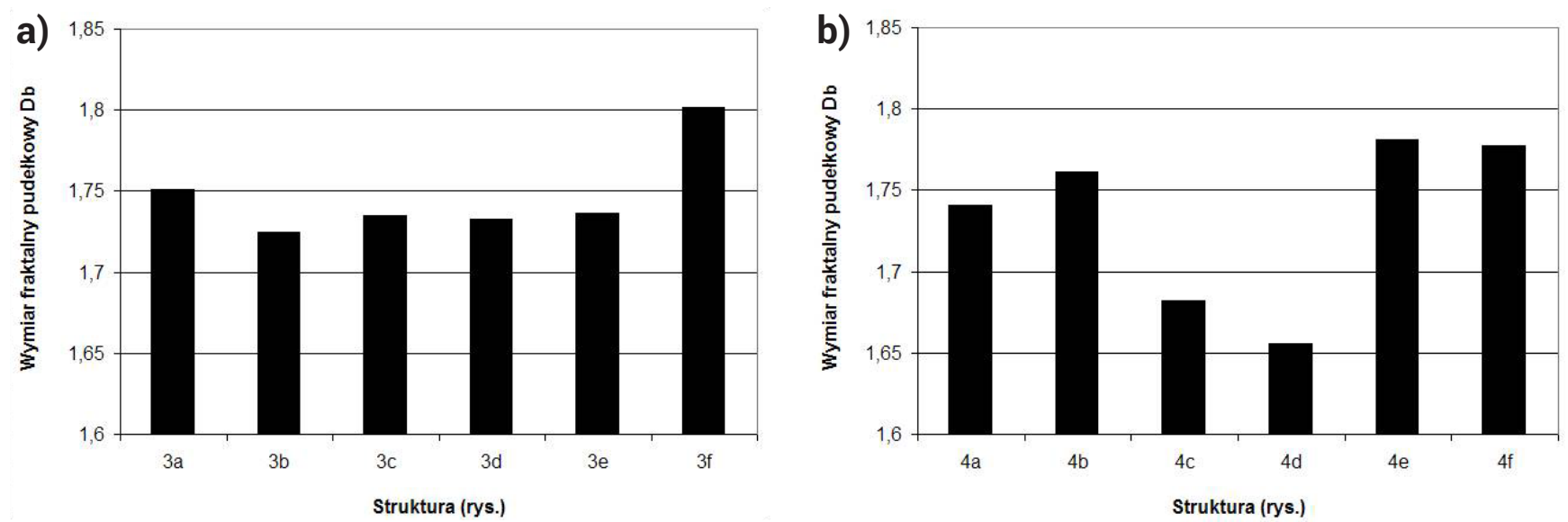

Rys. 5. Wymiar fraktalny pudełkowy $\left.D_{b} a\right)$ wariant I, b) wariant II

Fig. 5. Box fractal dimension $D_{b}$ a) variant $I, b$ ) variant II 
Tablica III. Wymiar fraktalny $D_{b}$, FDx i FDy badanych struktur

Table III. Fractal dimension $D_{b}$, FDx and FDy of analyzed structures

\begin{tabular}{|c|c|c|c|c|c|c|}
\hline Struktura (rys.) & $3 a$ & $3 b$ & $3 c$ & $3 d$ & $3 e$ & $3 f$ \\
\hline$D_{b}$ & 1,7509 & 1,7246 & 1,7349 & 1,7324 & 1,7362 & 1,8019 \\
\hline$F D x_{\text {min }}$ & 0,6521 & 0,6522 & 0,6459 & 0,7718 & 0,6784 & 0,6723 \\
\hline $\mathrm{FDx}_{\text {mean }}$ & 0,7959 & 0,7792 & 0,8074 & 0,8574 & 0,7880 & 0,8319 \\
\hline$F D x_{\max }$ & 0,9179 & 0,8664 & 0,9309 & 0,9329 & 0,8993 & 0,9466 \\
\hline $\mathrm{R}$ & 0,2658 & 0,2142 & 0,2849 & 0,1611 & 0,2209 & 0,2743 \\
\hline Var & 0,0025 & 0,0015 & 0,0039 & 0,001 & 0,0013 & 0,003 \\
\hline$S$ & 0,0505 & 0,0395 & 0,0624 & 0,0323 & 0,0372 & 0,0551 \\
\hline $\mathrm{CV}[\%]$ & 6,34 & 5,07 & 7,73 & 3,77 & 4,72 & 6,62 \\
\hline $\mathrm{FDy}_{\text {min }}$ & 0,6694 & 0,6754 & 0,6854 & 0,7510 & 0,6832 & 0,6015 \\
\hline $\mathrm{FDy}_{\text {mean }}$ & 0,7979 & 0,7765 & 0,8128 & 0,8607 & 0,7882 & 0,8265 \\
\hline $\mathrm{FDy}_{\max }$ & 0,9036 & 0,8714 & 0,9073 & 0,9216 & 0,8878 & 0,9545 \\
\hline $\mathrm{R}$ & 0,2342 & 0,1959 & 0,2219 & 0,1706 & 0,2045 & 0,3529 \\
\hline Var & 0,0016 & 0,0012 & 0,0014 & 0,001 & 0,0014 & 0,0065 \\
\hline S & 0,0406 & 0,0350 & 0,0378 & 0,0322 & 0,0385 & 0,0808 \\
\hline $\mathrm{CV}[\%]$ & 5,09 & 4,51 & 4,66 & 3,74 & 4,88 & 9,77 \\
\hline Struktura (rys.) & $4 a$ & $4 b$ & $4 c$ & $4 d$ & $4 e$ & $4 f$ \\
\hline$D_{b}$ & 1,7404 & 1.7612 & 1,6821 & 1,6557 & 1,7809 & 1,7774 \\
\hline $\mathrm{FDx}_{\text {min }}$ & 0,6659 & 0,6752 & 0,5820 & 0,6232 & 0,6898 & 0,6523 \\
\hline $\mathrm{FDx}_{\text {mean }}$ & 0,7873 & 0,8036 & 0,8026 & 0,7683 & 0,8218 & 0,8180 \\
\hline $\mathrm{FDx}_{\text {max }}$ & 0,8702 & 0,8832 & 0,9358 & 0,8717 & 0,9141 & 0,9622 \\
\hline $\mathrm{R}$ & 0,2043 & 0,2079 & 0,3537 & 0,2393 & 0,2242 & 0,3098 \\
\hline Var & 0,001 & 0,0016 & 0,0064 & 0,0015 & 0,0017 & 0,0032 \\
\hline$S$ & 0,033 & 0,041 & 0,0804 & 0,0389 & 0,0415 & 0,0569 \\
\hline $\mathrm{CV}[\%]$ & 4,19 & 5,11 & 10,01 & 5,07 & 5,05 & 6,96 \\
\hline $\mathrm{FDy}_{\text {min }}$ & 0,6651 & 0,7053 & 0,6924 & 0,6454 & 0,6845 & 0,6172 \\
\hline $\mathrm{FDy}_{\text {mean }}$ & 0,7866 & 0,8025 & 0,8124 & 0,7685 & 0,8200 & 0,8159 \\
\hline $\mathrm{FDy}_{\max }$ & 0,9141 & 0,9003 & 0,8889 & 0,8653 & 0,9121 & 0,9412 \\
\hline $\mathrm{R}$ & 0,2489 & 0,1950 & 0,1965 & 0,2198 & 0,2276 & 0,3240 \\
\hline Var & 0,0190 & 0,0013 & 0,0013 & 0,0013 & 0,0015 & 0,0045 \\
\hline$S$ & 0,0443 & 0,0366 & 0,0372 & 0,0362 & 0,0395 & 0,0677 \\
\hline $\mathrm{CV}[\%]$ & 5,63 & 4,56 & 4,57 & 4,71 & 4,81 & 8,30 \\
\hline \multicolumn{7}{|c|}{$\begin{array}{l}\text { FDx, } y_{\text {min }}-\text { wartość minimalna } \\
\text { FDx } \mathrm{y}_{\text {mean }}-\text { wartość średnia } \\
\text { FDx,y } \\
\text { R - rozstęp } \\
\text { Var - wartość maksymalna } \\
S \text { - odchylenie standardowe } \\
\text { CV - wsp. zmienności }\end{array}$} \\
\hline
\end{tabular}


a)

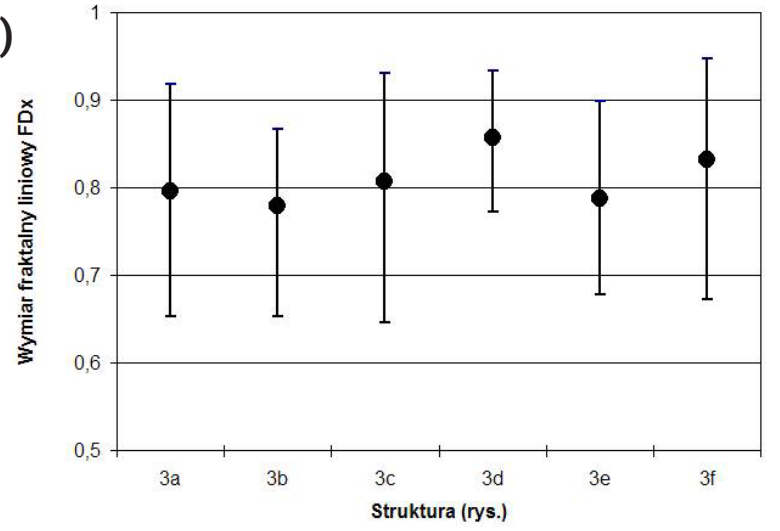

Rys. 6. Wymiar fraktalny liniowy FDx a) wariant I, b) wariant II

Fig. 6. Linear fractal dimension FDx a) variant I, b) variant II

a)

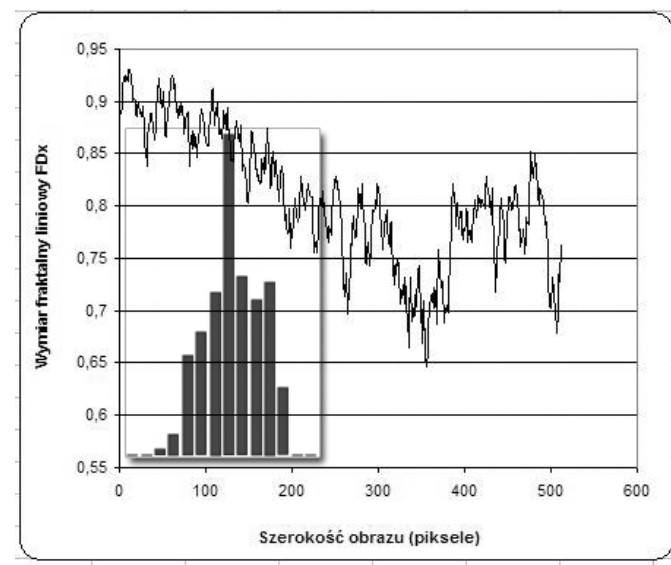

b)

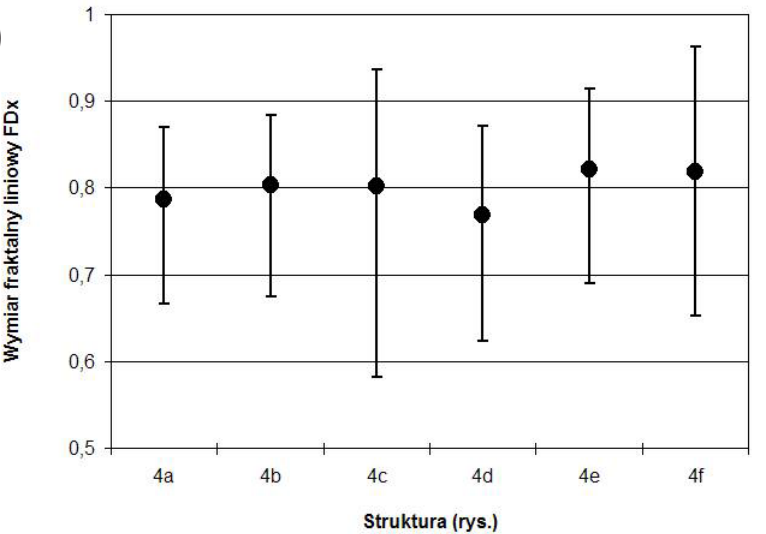

b)

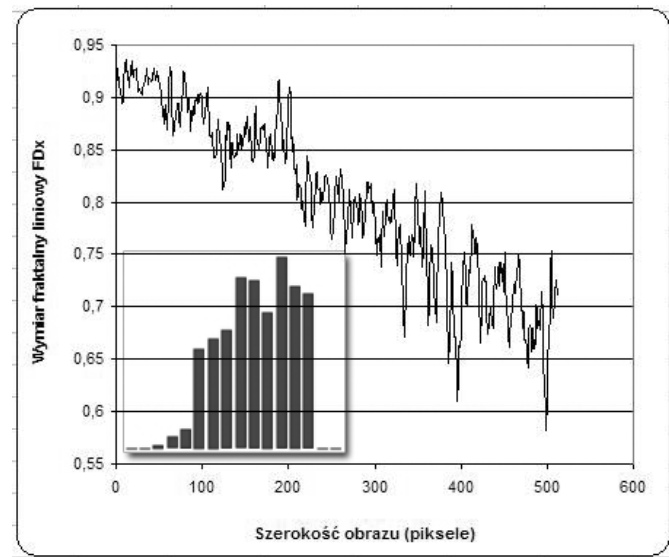

Rys. 7. Wymiar fraktalny liniowy FDx i histogramy rozkładu jego wartości dla obszaru linii wtopienia: a) wariant I, b) wariant II Fig. 7. Linear fractal dimension FDx and histograms of fractal dimension data set for fusion line zone a) variant I, b) variant II

\section{Podsumowanie}

Określana wartość wymiaru fraktalnego zależy od szeregu czynników. W szczególności otrzymana wartość wymiaru fraktalnego zależy od przyjętej metody jego określania oraz w przypadku struktur złączy, od staranności wykonania zgładów metalograficznych i właściwego ich wytrawienia. Na wartość wymiaru fraktalnego wpływa również zastosowana procedura przygotowania obrazów binarnych do analizy. Analizując otrzymane wartości wymiaru fraktalnego należy pamiętać, że zostały one określone dla wybranych struktur SWC złącza spawanego, różniących się między sobą nie tylko geometrią faz składających się na strukturę, ale co ważniejsze, również rodzajem struktury (sorbityczna, ferrytyczno - perlityczna).

W pracy przyjęto dwie metody określania wymiaru fraktalnego, w wyniku których otrzymano pudełkowy i liniowy wymiar fraktalny analizowanych struktur złączy. Wymiar pudełkowy pozwolił określić, w jakim stopniu elementy składowe struktury wypełniają analizowany obszar. Z kolei wymiar liniowy pozwolił na ocenę zmian w analizowanym obszarze, występujących wzdłuż przyjętych kierunków skanowania.

\section{Literatura}

[1] D. Avnir. The Fractal approach to heterogeneous chemistry: surfaces, colloids, polymers, John Wiley \& Sons Ltd. 1989.

[2] J. Chadwick: Calculation of the fractal dimension of grain boundaries in nanocrystalline, Pd, J. Phys.: Condens. Matter 11 (1999) 129-133.

[3] Xiaofan Gou, Justin Schwartz: Fractal analysis of the role of the rough interface between $\mathrm{Bi}_{2} \mathrm{Sr}_{2} \mathrm{CaCu}_{2} \mathrm{O}_{x}$ filaments and the $\mathrm{Ag}$ matrix in the mechanical behavior of composite round wires, Supercond. Sci. Technol. 26 (2013) 055016 (12pp) doi:10.1088/09532048/26/5/055016.

[4] J.A. Tesser, R.T. Lopes, A.P. Vieira, L.L. Goncalves, J.M.A. Rebello: Fractal Analysis of Weld Defect Patterns Obtained by Radiographic Tests, AIP Conf. Proc. 894, 539 (2007); doi:10.1063/1.2718018.

[5] M. Marek: Ocena fraktalna powierzchni krzepnięcia, Archiwum Odlewnictwa, Rok 2003, Rocznik 3, Nr 10.

[6] J. Grześ: Wymiar fraktalny gradientowej warstwy pośredniej $\mathrm{Al}_{2} \mathrm{O}_{3}-\mathrm{Cr}$, Przegląd Spawalnictwa Vol 85, No 1 (2013).

[7] J. Górka: Przemiany strukturalne stali S700MC w warunkach oddziaływania symulowanych cykli cieplnych spawania, Przegląd Spawalnictwa Vol 87 , No 10 (2015)
[8] R. Tadeusiewicz, I. Jastrzębska, R. Jastrzębski: Możliwości stworzenia maski spawalniczej z komputerowym przetwarzaniem przestrzennego obrazu zamiast filtrów spawalniczych, Przegląd Spawalnictwa Vol 88, No 1 (2016).

[9] G. Sypniewski: Metody wizyjne w automatyzacji spawania, Przegląd Spawalnictwa Vol 87, No 1 (2015).

[10] H.-O. Peitgen, H. Jürgens, D. Saupe: Granice chaosu - Fraktale, Wydawnictwo Naukowe PWN, Warszawa 1997.

[11] L. S. Liebovitch, T. Toth: A Fast Algorithm to Determine Fractal Dimensions by Box Counting" Physics Letters A, Vol. 141/No. 8,9, Holland 1989.

[12] N. Sarker, B.B. Chaudhuri: An efficient differential box-counting approach to compute fractal dimension of image, IEEE Transactions on Systems, Man, and Cybernetics 24 (1994) 115-120.

[13] Jian Li, Qian Du, Caixin Sun: An improved box-counting method for image fractal dimension estimation, Pattern Recognition 42 (2009) 2460-2469.

[14] S. Buczkowski, S. Kyriacos, F. Nekka, L. Cartilier: The modified boxcounting method: analysis of some characteristics parameters, Pattern Recognition 3 (1998), s. 411-418.

[15] J. Grześ: Wymiar fraktalny wybranych struktur złącza spawanego ze stali H17, Prace Naukowe - Mechanika 2009, 229, s. 23-31. 